\title{
Estimasi cadangan karbon biomassa di atas permukaan pada tegakan mangrove menggunakan pengindraan jauh di Tongke-Tongke, Sulawesi Selatan
}

\section{Mangrove's carbon stock estimation using remote sensing in Tongke-Tongke, South Sulawesi}

Vina Nurul Husna ${ }^{\mathrm{a}}$, Vincentius P. Siregar ${ }^{\mathrm{a}}$, Syamsul B. Agus ${ }^{\mathrm{a}}$, Taslim Arifin ${ }^{\mathrm{b}}$

${ }^{a}$ Departemen Ilmu dan Teknologi Kelautan, Fakultas Perikanan dan Ilmu Kelautan, Institut Pertanian Bogor, Kampus IPB Darmaga Bogor, 16680, Indonesia

${ }^{\mathrm{b}}$ Pusat Riset Kelautan, BRSDMKP-Kementerian Kelautan Perikanan, Indonesia

\section{Article Info:}

Received: 19 - 05 - 2018

Accepted: $10-08-2018$

Keywords:

carbon stock, remote sensing,

Tongke-tongke

Corresponding Author:

Vina Nurul Husna

Departemen Ilmu dan Teknologi

Kelautan, Fakultas Perikanan

dan Ilmu Kelautan, Institut

Pertanian Bogor

Email:

vinahusna@gmail.com

\begin{abstract}
Mangrove is one of the most intensive carbon sinks and plays a major role in the carbon cycle. However, the existence of mangrove is decreasing due to land use change that are not in accordance with its allocation, and disrupt the carbon cycle in the ecosystem. This study aims to estimate mangrove carbon stock using remote sensing technique in Tongketongke, South Sulawesi. Estimation using remote sensing usually has a low accuracy, therefore this research use multispectral (Landsat) and radar (PALSAR) sensor to increase the accuracy. Total carbon stocks in the study area based on model built for $H H$ and HV polarization were 5662.85 ton and 6431.46 ton, respectively.
\end{abstract}

\section{How to cite (CSE Style $8^{\text {th }}$ Edition):}

Husna VN, Siregar VP, Agus SB, Arifin T. 2019. Estimasi cadangan karbon biomassa di atas permukaan pada tegakan mangrove menggunakan pengindraan jauh di Tongke-Tongke, Sulawesi Selatan. JPSL 9(2): 456-466. http://dx.doi.org/10.29244/jpsl.9.2. 456-466.

\section{PENDAHULUAN}

Isu utama dalam perubahan iklim akibat peningkatan suhu global adalah peningkatan kandungan gas karbondioksida $\left(\mathrm{CO}_{2}\right)$ di atmosfer (Cramer et al. 2001; Weiss dan Leip 2012). Pada saat yang sama, jumlah hutan/pohon yang mampu menyerap gas $\mathrm{CO}_{2}$ di atmosfer semakin berkurang akibat illegal logging atau konversi lahan. Hasilnya, jumlah kandungan $\mathrm{CO}_{2}$ di atmosfer meningkat hingga 400 ppm pada tahun 2013, dibandingkan pada tahun 1750 konsentrasi $\mathrm{CO}_{2}$ hanya 281 ppm (NASA 2018). Salah satu cara untuk mengurangi kandungan gas $\mathrm{CO}_{2}$ di atmosfer adalah dengan metode carbon sequestration yaitu dengan menangkap karbon di atmosfer dan menyimpannya dalam vegetasi (biomassa). Pengukuran biomassa vegetasi yang salah satunya berupa banyaknya $\mathrm{CO}_{2}$ di atmosfer yang diserap oleh tanaman, dapat disebut sebagai karbon stok dengan pembagian di atas permukaan tanah dan di bawah permukaan tanah.

Hutan mangrove merupakan salah satu penyerap karbon yang intensif dan mempunyai peranan yang besar dalam siklus karbon dunia (Howard et al. 2014; Wicaksono et al. 2016). Hutan mangrove juga memiliki potensi yang tinggi sebagai carbon sequestration dan mewakili $1 \%$ dari carbon sequestration 
global dan 14\% di kawasan pesisir (Alongi 2014). Ekosistem mangrove merupakan salah satu ekosistem yang paling produktif di muka bumi. Mangrove merupakan hutan dengan vegetasi halofit ditemukan di daerah pesisir, terutama di muara sungai dan pada laguna di daerah tropis dan subtropik yang berfungsi penting untuk ekologis dan sosial-ekonomi (FAO 2007). Ekosistem mangrove memiliki peran yang sangat penting dalam hal dinamika lingkungan pesisir dan lautan itu sendiri, antara lain sumber bahan organik dan nutrient (Haryadi dan Hadiyanto 2012) sebagai habitat berbagai jenis ikan dan udang untuk mencari makan, memijah, berlindung dan bertelur (Zagars et al. 2013), habitat berbagai jenis fauna (Das 2017; Leung 2015), dapat digunakan sebagai media pembelajaran dan rekreasi (Wijayanto et al. 2013; Salam et al. 2000), menyerap karbon dalam perubahan iklim global (Hilmi 2017; Ahmed dan Glaser 2016; Alongi 2014), pelindung pantai dari erosi, tiupan angin dan ombak (Alongi 2008) dan penghasil kayu serta sumber daya lainnya (Aziz et al. 2015; Ewel et al. 1998).

Namun, eksistensi mangrove semakin menurun karena adanya perubahan penggunaan lahan yang tidak sesuai dengan peruntukannya. Ekosistem pesisir mengalami kerusakan 340000 sampai 980000 hektar tiap tahunnya (Sifleet et al. 2011). Termasuk berkurangnya ekosistem mangrove di Indonesia yang penyebabnya didominasi oleh konversi dari lahan mangrove ke tambak (Fawzi 2016). Data rehabilitasi hutan dan lahan tahun 2011 menunjukkan bahwa penanaman mangrove baru terealisasi seluas 10.431 hektar (Departemen Kehutanan 2011). Hasil pengamatan lapang dan data tersebut menunjukkan bahwa tingkat keberhasilan rehabilitasi mangrove hanya sekitar 1.973 hektar per tahun (Yanuartanti et al. 2016). Inventarisasi mangrove perlu dilakukan agar mengetahui perubahan luasan mangrove dari tahun ke tahun dan kemudian dapat dilakukan analisis siklus karbon yang terjadi di ekosistem tersebut (Howard et al. 2014). Pemanfaatan teknologi pengindraan jauh mampu memenuhi kebutuhan inventarisasi hutan mangrove karena mampu untuk meminimalkan biaya, waktu dan tenaga dibandingkan dengan pengamatan langsung di lapangan.

Penelitian ini menggunakan citra multispektral yaitu Landsat dan citra radar yaitu PALSAR. Penggunaan dua citra yang berbeda sensor karena analisis stok karbon yang tersimpan di biomassa pohon merupakan kenampakan 3 dimensi, sedangkan citra multispektral hanya mampu menampilkan informasi dua dimensi. Oleh karena itu, menggunakan citra radar yang mampu menampilkan informasi 3 dimensi. Landsat sering digunakan peneliti untuk pemetaan mangrove (Fei et al. 2011). Banyak penelitian mengenai pemetaan mangrove menggunakan citra Landsat, diantaranya adalah klasifikasi zonasi ekologi hutan mangrove di India menggunakan Landsat tahun 1999 dan 2010 dengan akurasi sebesar 80\% dan 85.71\% dan menghasilkan 6 kelas spesies mangrove yaitu Avicennia sp, Excoecaria sp, Phoenix sp, Bruguiera sp, Ceriops sp dan kelas campuran (Giri et al. 2014). Untuk pemetaan mangrove juga telah dilakukan oleh Opa (2010), yaitu dengan menganalisis perubahan luasan mangrove di Kabupaten Pohuwanto, Provinsi Gorontalo menggunakan Landsat TM. PALSAR dipilih untuk penelitian ini karena menggunakan L-band dimana band tersebut memiliki kemampuan untuk menghasilkan informasi sampai ke volume batang. Jika dibandingkan dengan citra gelombang mikro lain yang menggunakan band yang lebih pendek seperti $\mathrm{X}$ dan $\mathrm{C}$, gelombang $\mathrm{X}$ dan $\mathrm{C}$ tersebut hanya mampu mengekstraksi informasi sampai ke cabang-cabang kecil sehingga informasi volume pohon tidak dapat diperoleh (Goetz et al. 2009). Penelitian ini bertujuan untuk estimasi cadangan biomassa karbon di atas permukaan tanah mangrove menggunakan pengindraan jauh.

\section{METODE}

\section{Lokasi dan Waktu Penelitian}

Penelitian ini dilaksanakan di ekosistem mangrove Desa Tongke-tongke di Kabupaten Sinjai, Sulawesi Selatan dan survei lapang dilaksanakan pada bulan Oktober 2016. Gambar 1 menunjukkan peta penggunaan lahan di daerah Tongke-tongke dan sekitarnya. Pada Gambar 1 terdapat area yang diberi tanda merah yang merupakan daerah kajian dalam penelitian yaitu kawasan mangrove Tongke-tongke. 


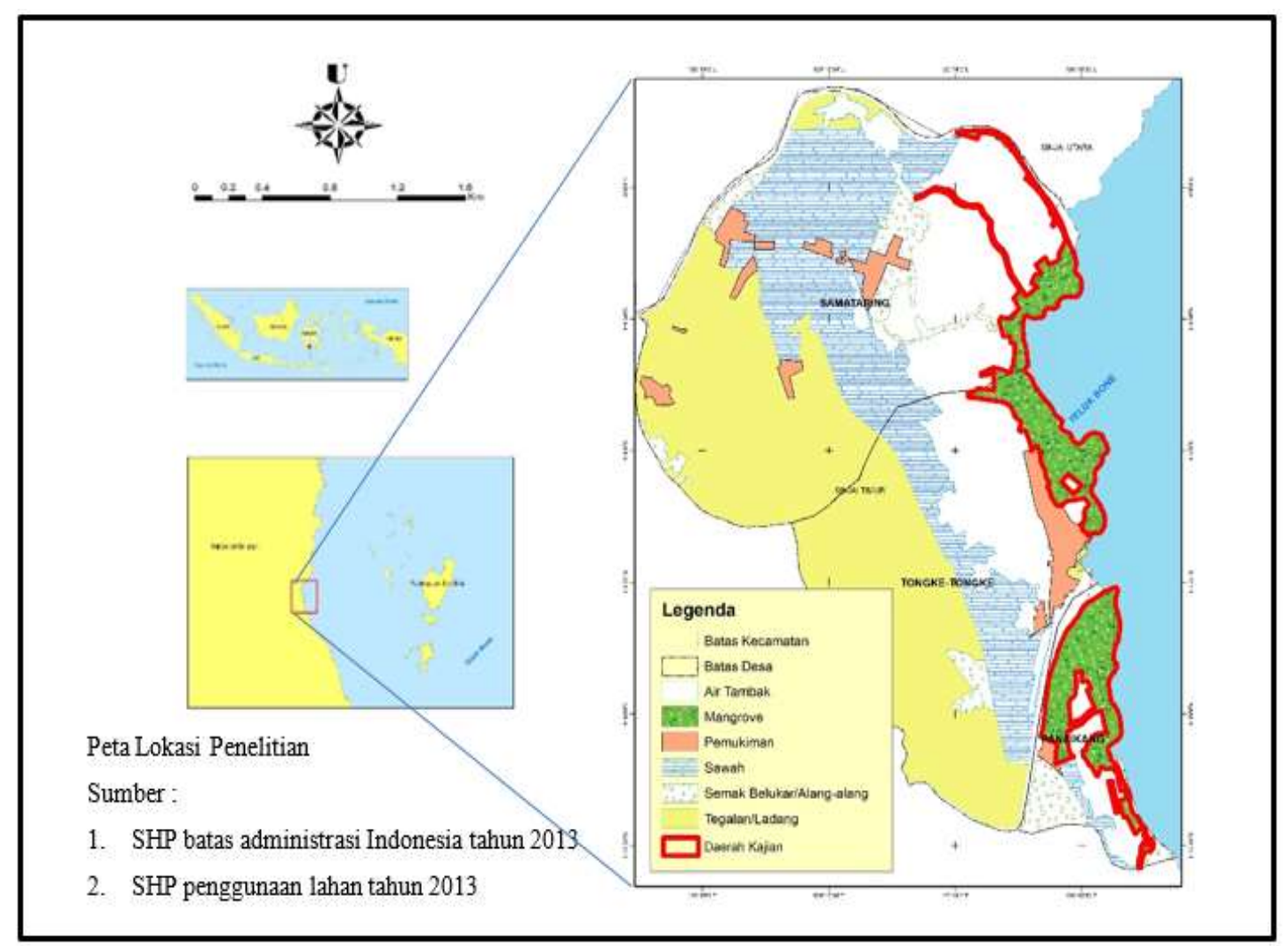

Gambar 1 Peta penggunaan lahan Tongke-Tongke

\section{Alat dan Bahan}

Perangkat lunak yang digunakan untuk pengolahan data terdiri dari Microsoft Office 2013, ENVI 5.1 dan ArcGIS 10.4.1. Peralatan yang digunakan pada saat survei lapangan terdiri dari Global Positioning System, kamera dan pita ukur. Data citra yang digunakan dalam penelitian ini antara lain citra Landsat 7 ETM dengan perekaman tanggal 14 Oktober 2008, citra Landsat 8 OLI dengan perekaman tanggal 26 September 2016 dan citra RADAR yaitu ALOS-PALSAR dengan perekaman tanggal 9 September 2008.

\section{Metode Pengumpulan Data}

\section{Pengolahan data citra}

Pada citra Landsat 7 ETM dan Landsat 8 OLI dilakukan proses koreksi yang terdiri dari koreksi geometrik, radiometrik dan atmosferik. Citra yang sudah terkoreksi tersebut kemudian dilakukan proses klasifikasi multispektral dengan metode maximum likelihood untuk membedakan mangrove dan nonmangrove. Hasil klasifikasi tersebut dijadikan sebagai dasar masking citra, untuk mendapatkan citra hanya daerah mangrove saja. Hasil citra masking dilakukan proses transformasi indeks vegetasi. Hal yang sama juga dilakukan pada citra PALSAR. Pada citra PALSAR dilakukan kalibrasi untuk mengubah nilai pixel menjadi nilai dengan satuan decibel $(\mathrm{dB})$. Citra yang sudah terkalibrasi kemudian dilakukan masking menggunakan hasil klasifikasi dari Landsat 7 ETM untuk menghasilkan citra PALSAR dengan cakupan daerah mangrove saja. Pada citra Landsat 7 dan Landsat 8 diterapkan transformasi Normalized Difference Vegetation Index (NDVI) dengan rumus berikut:

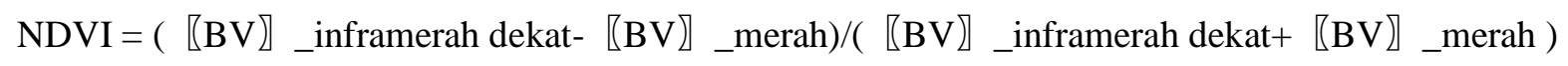




\section{Survei lapang}

Pada tahap survei lapang, pengambilan data dilakukan dengan menggunakan transek, dimana di setiap transek diambil data jenis mangrove dan diameter pohon. Transek dibuat berdasarkan metode dari Kauffman dan Donato (2012) dimana transek disesuaikan dengan bentuk pixel yaitu persegi (Gambar 2). Transek berukuran $(10 \times 10)$ meter. Pengambilan sampel berdasar metode purposive random sampling dimana mempertimbangkan aksesibilitas dan keragaman jenis mangrove.

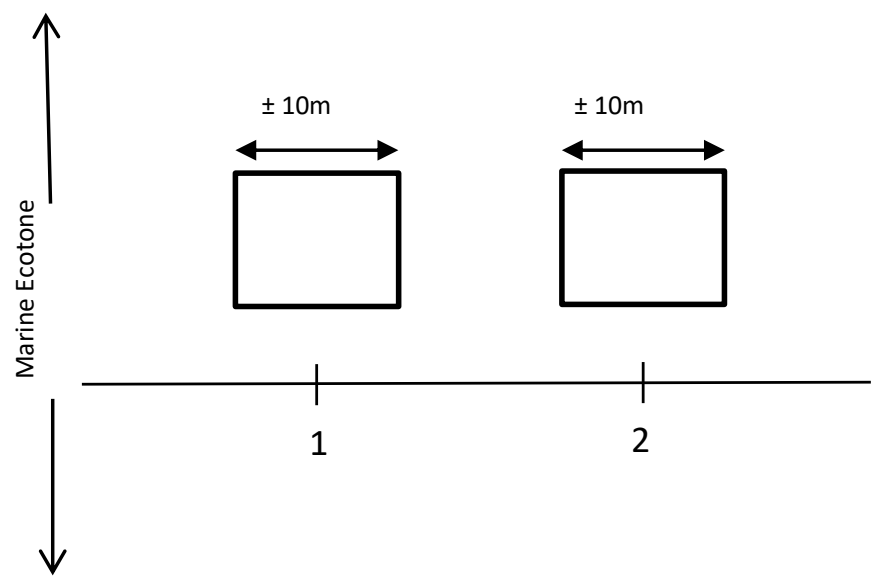

Gambar 2 Contoh transek sampel

Perhitungan cadangan karbon di lapangan menggunakan model persamaan allometrik jenis-jenis pohon mangrove yang sudah ada (Sutaryo 2009). Diameter pohon atau dbh (diameter at breast height) digunakan sebagai parameter penduga biomassa. Dbh merupakan besaran diameter pohon yang diukur setinggi dada orang dewasa atau kurang lebih 1.3 meter dari permukaan tanah.

\section{Metode Analisis Data}

Titik sampel pengukuran di lapangan kemudian diplotkan ke citra NDVI Landsat 8 untuk mengetahui besar nilai NDVI dengan nilai karbon di tiap titiknya. Setelah mendapatkan nilai NDVI tersebut kemudian dilakukan pencarian nilai NDVI yang sama di citra NDVI Landsat 7 ETM. Dari proses tersebut dihasilkan letak titik yang memiliki nilai NDVI yang sama dengan lokasi sampel. Titik tersebut kemudian dilakukan overlay pada citra PALSAR untuk mengetahui nilai backscatter pada polarisasi HH dan HV. Nilai backscatter dan nilai karbon dilakukan 3 macam regresi yaitu regresi linear, quadratic dan exponential. Nilai R2 terbesar digunakan sebagai algoritma dasar pembentukan peta persebaran karbon di daerah kajian. Peta persebaran karbon tersebut kemudian diuji akurasi dengan jumlah sisa sampel yang tidak digunakan untuk membangun algoritma. Langkah-langkah dalam penelitian disajikan pada Gambar 3 berikut. 


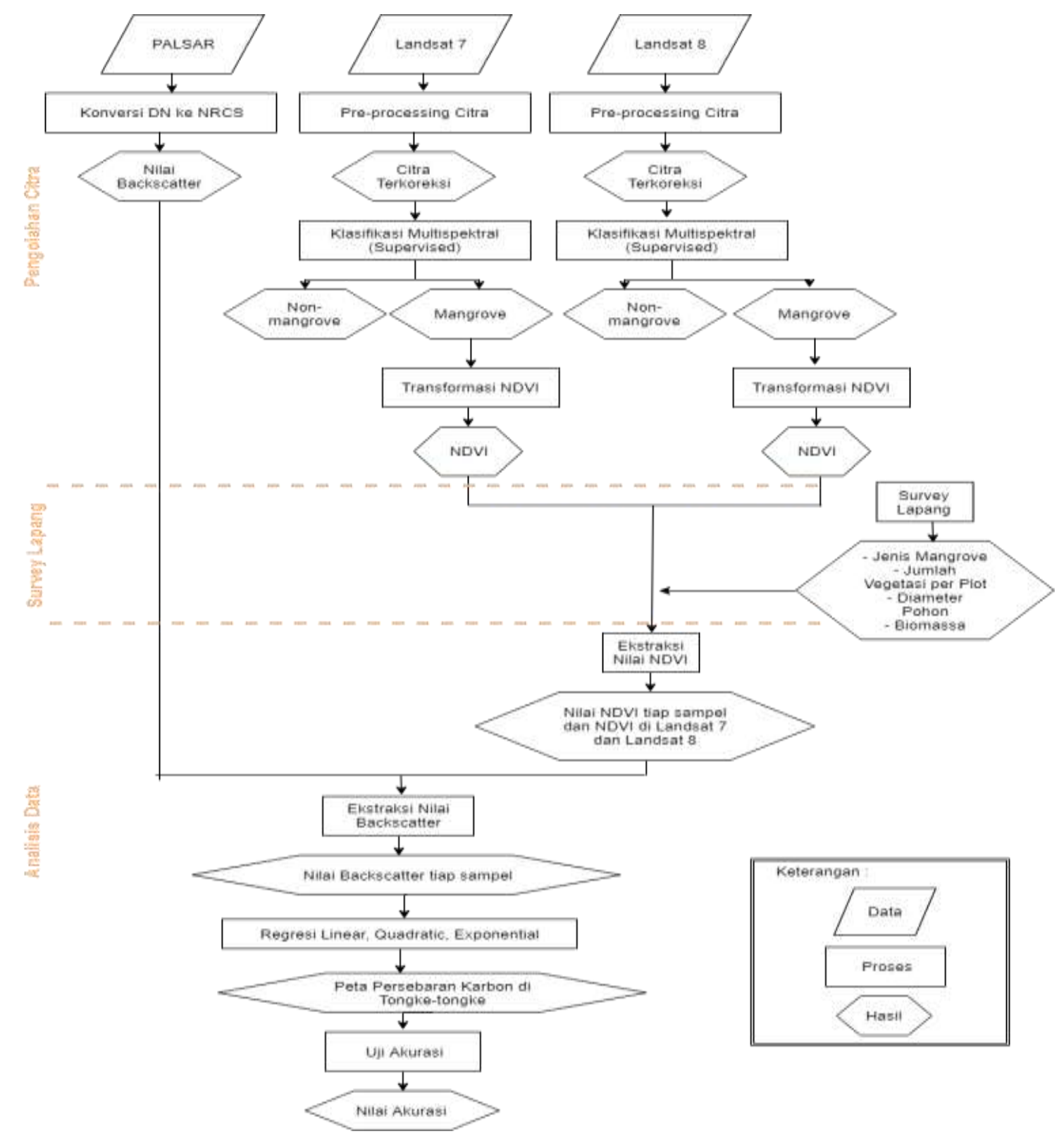

Gambar 3 Diagram alir penelitian

\section{HASIL DAN PEMBAHASAN}

\section{Hasil Pengolahan Citra}

Hasil transformasi NDVI menunjukkan bahwa pada Landsat 7 memiliki range nilai NDVI 0.044 sampai 0.682 , sedangkan Landsat 8 memiliki range nilai NDVI yang lebih tinggi yaitu 0.029 sampai 0.915 . Semakin mendekati nilai NDVI 1 maka vegetasi tersebut memiliki kerapatan yang lebih tinggi. Maka dari kedua citra tersebut terlihat bahwa Landsat 8 memiliki kerapatan yang lebih tinggi dibandingkan dengan Landsat 7 . Hal ini bisa disebabkan pada saat perekaman citra Landsat 7 yaitu tahun 2008, mangrove tersebut masih berupa anakan atau baru dilakukan penanaman, dan disaat perekaman citra Landsat 8 tahun 2016 mangrove tersebut sudah tumbuh besar dan memiliki kerapatan tajuk yang lebih luas dan tinggi sehingga menghasilkan nilai NDVI yang lebih tinggi juga. Nilai NDVI semakin tinggi ketika umur pohon bertambah dan diiringi dengan pertambahan luas kanopi (kerimbunan) dan bertambahnya diameter pohon. Bertambahnya luas kanopi pohon akan meningkatkan kandungan klorofil di area tersebut, klorofil yang semakin tinggi maka juga akan 
meningkatkan kandungan hijau yang kemudian berdampak pada reflektan spektrum hijau meningkat. Peningkatan reflektan spektrum hijau menyebabkan nilai NDVI di area tersebut juga semakin tinggi. Terdapat korelasi yang kuat antara ukuran diameter pohon dengan nilai NDVI (Wang et al. 2004).

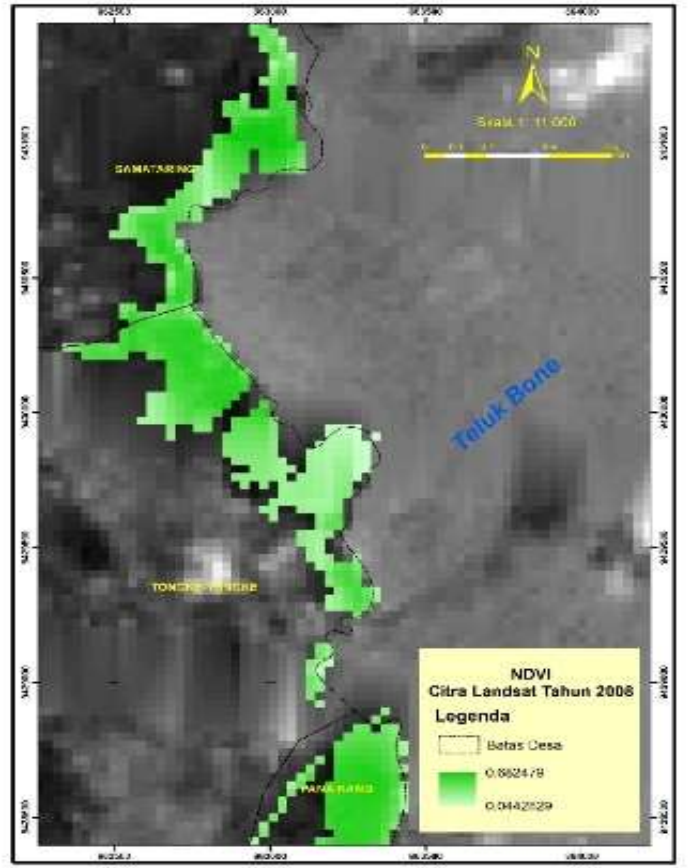

(a)

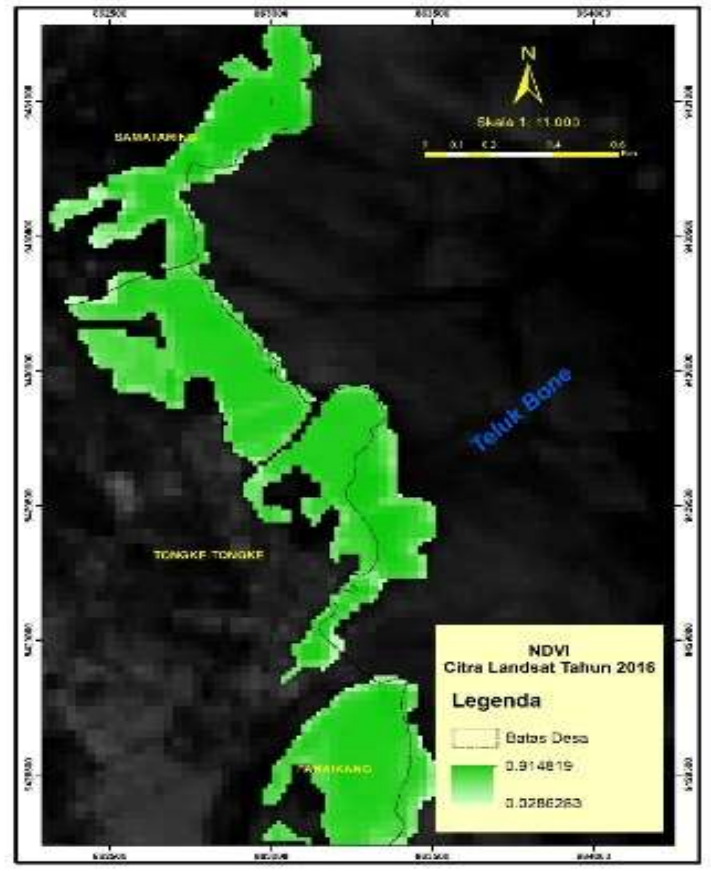

(b)

Gambar 4 Transformasi NDVI citra Landsat ETM (a) dan Landsat 8 (b)

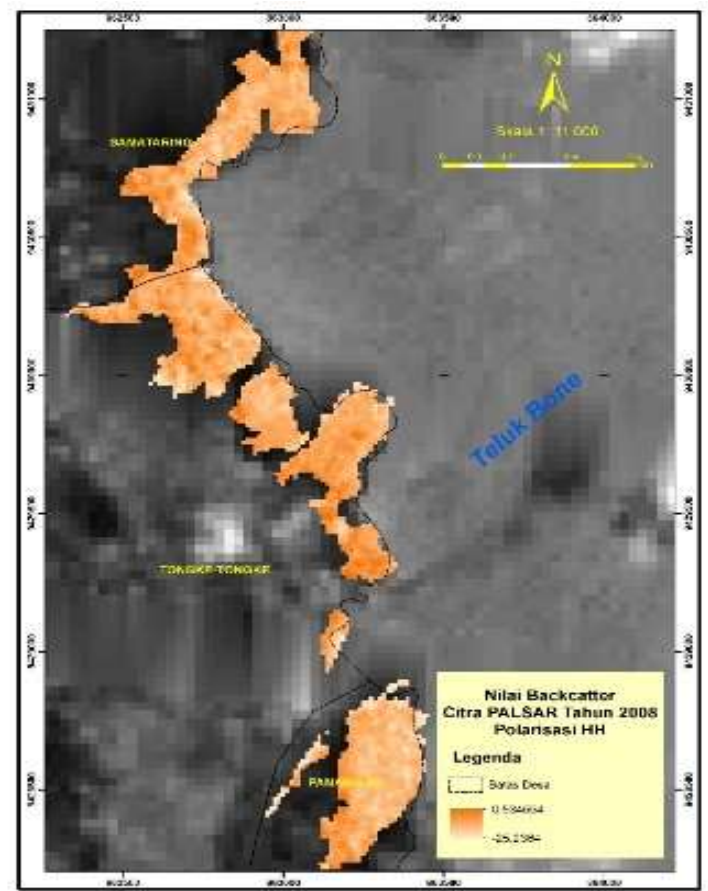

(a)

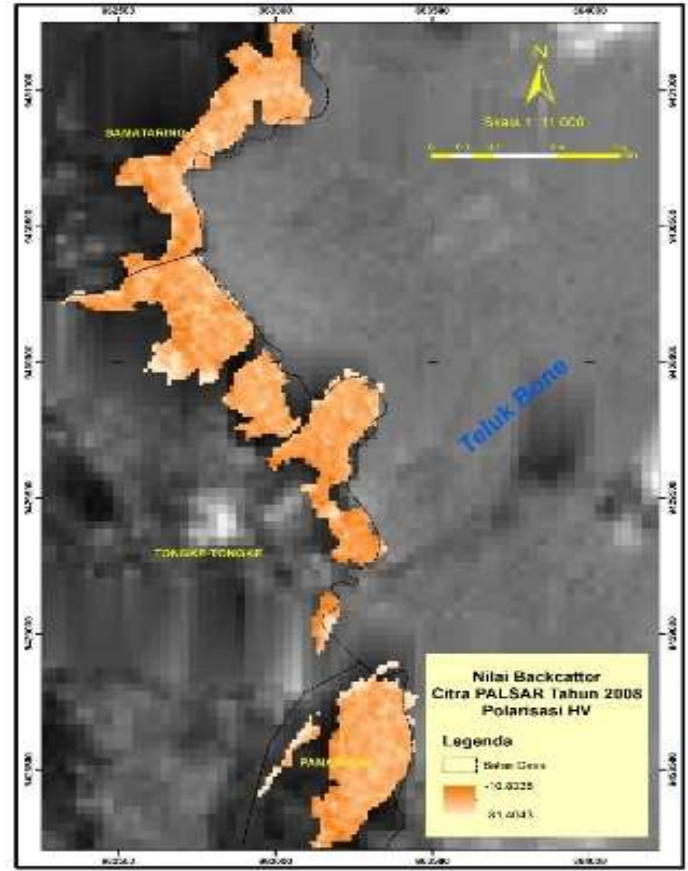

(b)

Gambar 5 Nilai backscatter polarisasi HH (a) dan polarisasi HV (b) 
Gambar 5 menunjukkan citra hasil konversi nilai DN menjadi backscatter dengan polarisasi $\mathrm{HH}$ dan HV untuk daerah mangrove. Kedua polarisasi ini menghasilkan nilai yang cukup berbeda, dimana $\mathrm{HH}$ memiliki nilai yang lebih besar daripada polarisasi HV. Pada polarisasi $\mathrm{HH}$ memiliki nilai backscatter dengan variasi nilai dari -25.2364 sampai 0.534554. Sedangkan polarisasi HV memiliki nilai backscatter yang lebih rendah daripada polarisasi HH yaitu dari -31.0023 sampai -9.11743 .

\section{Analisis Data}

Hasil survei lapangan menunjukkan bahwa di kawasan Tongke-tongke terdapat 5 jenis mangrove yaitu Rhizophora sp, Sonneratia sp, Xylocarpus sp, Avicennia sp dan Nypa fruticans. Rhizopora sp merupakan jenis yang mendominasi $85 \%$ kawasan mangrove Tongke-tongke. Sedangkan jenis lain hanya menempati $15 \%$ di kawasan tersebut. Total sampel yang diperoleh di lapangan sebanyak 19 sampel, dapat dilihat pada Gambar 6 berikut.

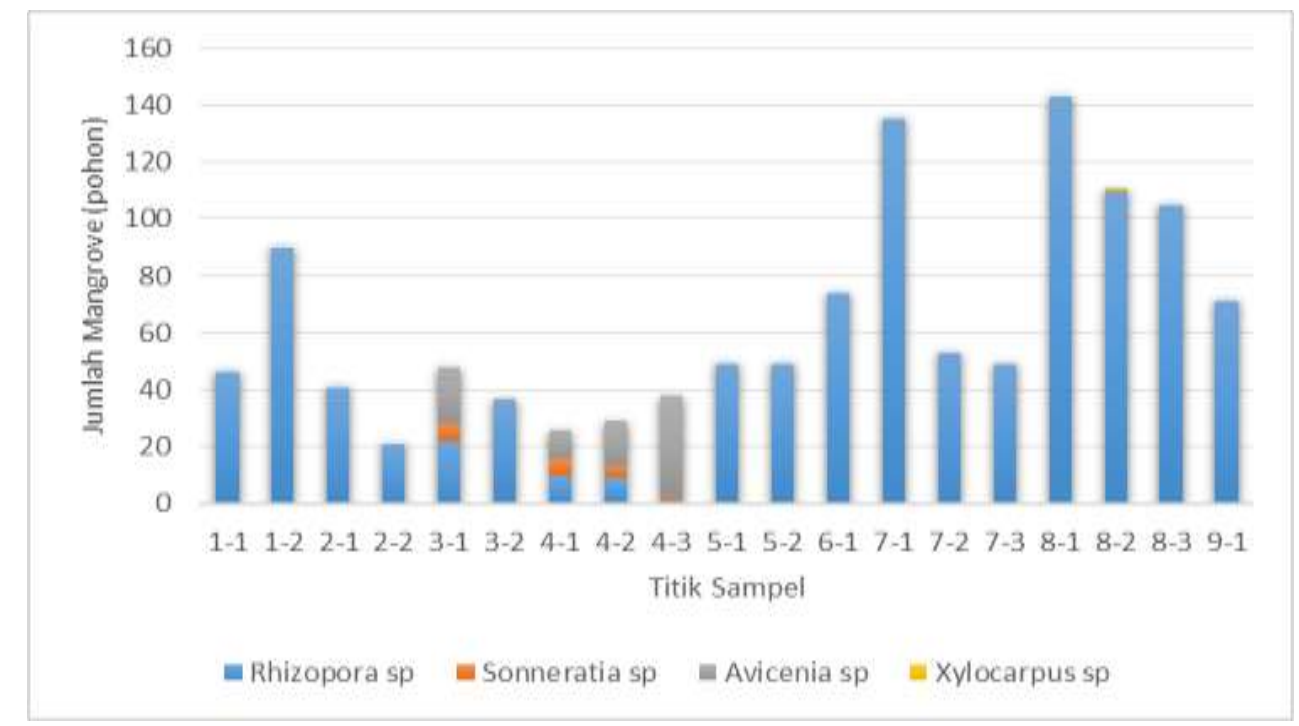

Gambar 6 Grafik persebaran jenis mangrove per sampel

Model penduga atau estimasi stok karbon yang digunakan dalam penelitian ini menggunakan perantara citra multispektral Landsat 7 yang diekstrak nilai NDVI di bagian mangrove yang kemudian dibandingkan dengan nilai backscatter pada citra PALSAR. Nilai NDVI pada citra Landsat 8 menjadi referensi dalam proses penelitian ini, karena pada tahun tersebut terdapat data lapangan yang bersifat terbaru. Nilai NDVI pada citra Landsat 8 kemudian dicari nilai yang sama dengan nilai NDVI di citra Landsat ETM. Posisi nilai NDVI di Landsat ETM digunakan untuk ekstraksi nilai backscatter pada citra PALSAR tahun 2008.

Nilai backscatter tersebut selanjutnya dianalisis secara statistik berupa regresi terhadap nilai stok karbon dengan 3 jenis berbeda yaitu linier, quadratic dan exponential (Tabel 1). Salah satu hal terpenting dalam regresi adalah penetuan variable dependent yaitu nilai stok karbon dan independent yaitu nilai backscatter.

Dari ketiga jenis regresi tersebut, regresi quadratic menghasilkan koefisien determinasi yang paling tinggi di masing-masing polarisasi sehingga persamaan regresi quadratic yang digunakan sebagai model penduga atau estimasi stok karbon. Berikut persamaan regresi quadratic untuk polarisasi $\mathrm{HH}: \mathrm{y}=-5.473-$ $1.318 \mathrm{x}-0.066 \mathrm{x}^{2}$, dengan $\mathrm{y}$ adalah karbon dan $\mathrm{x}$ adalah nilai hamburan balik polarisasi HH. Sedangkan untuk polarisasi HV menggunakan persamaan $\mathrm{y}=30.654+2.774 \mathrm{x}+0.064 \mathrm{x}^{2}$. Besarnya koefisien determinasi menunjukkan bahwa pengaruh variable independent (polarisasi $\mathrm{HV}$ ) terhadap simpanan karbon pada area kajian sebesar $62.9 \%$ sedangkan sisanya sebesar $37.1 \%$ dipengaruhi oleh variabel lain yang tidak dimasukkan dalam penelitian ini.

Tabel 1 Nilai hubungan stok karbon dan backscatter 


\begin{tabular}{lclccc}
\hline \multicolumn{1}{c}{ Regresi } & Polarisasi & \multicolumn{1}{c}{ Persamaan } & R & $\mathbf{R}^{2}$ & SE \\
\hline \multirow{2}{*}{ Linear } & HH & $y=2.528+0.146 x$ & 0.681 & 0.464 & 0.233 \\
& HV & $y=4.264+0.172 x$ & 0.761 & 0.579 & 0.207 \\
Quadratic & HH & $y=-5.473-1.318 x-0.066 x^{2}$ & 0.767 & 0.588 & 0.221 \\
& HV & $y=30.654+2.774 x+0.064 x^{2}$ & 0.793 & 0.629 & 0.210 \\
\multirow{2}{*}{ Exponential } & HH & $y=9.097 e^{0.214 x}$ & 0.647 & 0.418 & 0.374 \\
& HV & $y=137.261 e^{0.261 x}$ & 0.749 & 0.561 & 0.325 \\
\hline
\end{tabular}

Persamaan regresi yang digunakan sebagai dasar model estimasi stok karbon adalah persamaan regresi quadratic, yang selanjutnya dijadikan sebagai dasar pembuatan model sebaran estimasi stok karbon. Persamaan tersebut kemudian diterapkan pada citra PALSAR untuk estimasi jumlah stok karbon di daerah lain, dijelaskan pada Gambar 4. Sampel yang digunakan untuk membangun persamaan model dalam regresi adalah sampel yang memiliki jenis mangrove yang homogen yaitu Rhizophora sp. Sampel dengan jenis tersebut dipilih untuk membangun model, karena dari keseluruhan wilayah kajian, jenis Rhizophora sp. merupakan jenis mangrove yang mendominasi wilayah kajian yaitu sekitar $85 \%$. Pada saat diterapkan pada citra PALSAR untuk estimasi stok karbon, tetap menggunakan persamaan yang berasal dari sampel Rhizophora sp., meskipun di daerah kajian juga terdapat jenis mangrove yang lain. Jenis mangrove lain memiliki luasan yang sangat sedikit kurang lebih hanya 15\% dari bagian wilayah kajian sehingga dianggap tidak terlalu memberikan perbedaan yang jauh terhadap nilai estimasi stok karbon.

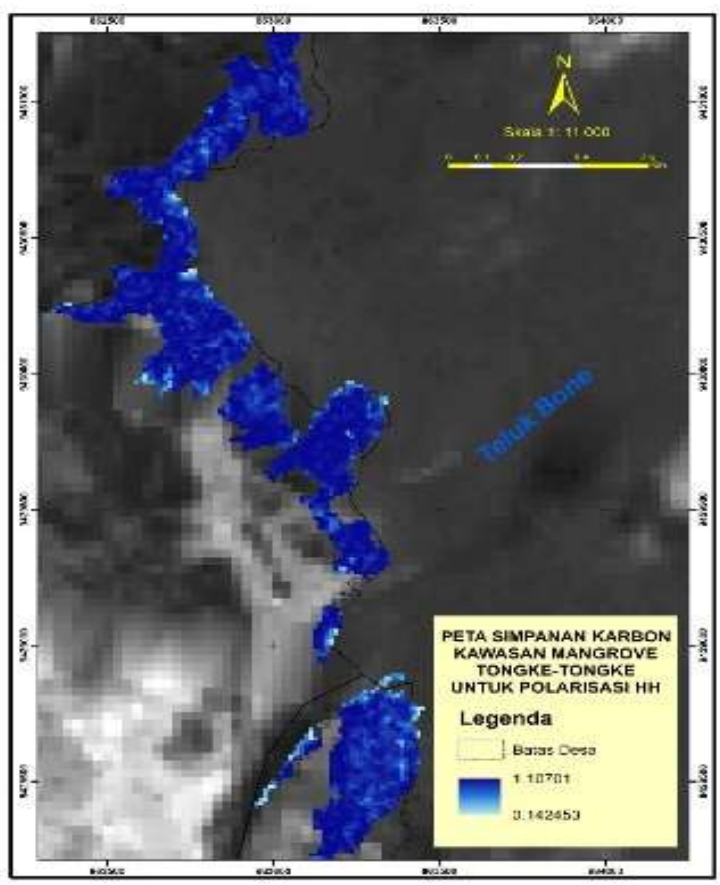

(a)

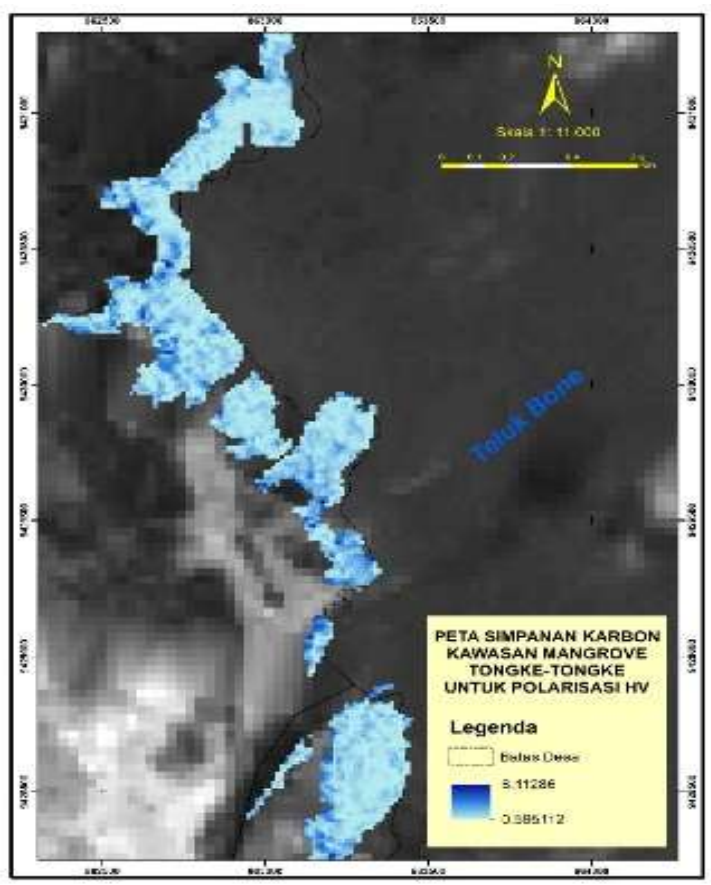

(b)

Gambar 4 Persebaran nilai stok karbon di Tongke-Tongke, polarisasi HH (a), Polarisasi HV (b)

Total stok karbon di daerah kajian berdasarkan model yang dibangun untuk polarisasi HH dan HV masing-masing sebesar 5662.85 ton dan 6431.46 ton. Nilai total stok karbon tersebut merupakan nilai stok karbon untuk tahun 2008. Analisis mengenai stok karbon di masa lampau sangat jarang ditemui karena ada kendala dalam hal ketersediaan data. Penelitian ini mencoba melakukan analisis nilai stok karbon di masa lampau yaitu tahun 2008 dengan menggunakan data perantara tahun 2016. Hasil analisis pada tahun 2008 dapat digunakan untuk analisis lebih lanjut terkait monitoring stok karbon dari waktu ke waktu. 
Hasil estimasi nilai stok karbon diuji dengan menggunakan Standart Error of Estimation (SE). Sampel yang digunakan untuk melakukan uji akurasi sebanyak 9 sampel yang tersisa dari keseluruhan sampel yang diperoleh di lapangan, dimana sebagian besar sampel lain sudah dipergunakan untuk membangun model. Nilai akurasi ditentukan berdasarkan besar nilai SE antara hasil pengukuran karbon di lapangan dengan citra. Tabel 2 menunjukkan hasil estimasi karbon.

Pada Tabel 2 terl ihat terdapat perbedaan karbon estimasi antara polarisasi HH dan HV. Namun perbedaan tersebut tidak terlalu jauh di masing-masing polarisasi. Nilai standart error of estimates (SE) untuk polarisasi HH sebesar 0.383 sedangkan untuk polarisasi HV sebesar 0.357 . Nilai SE sebesar 0.357 dapat diartikan sebagai tingkat kesalahan estimasi karbon sebesar 0.357 per sampel. Semakin mendekati nilai SE 0 maka tingkat ketelitian estimasi semakin tinggi atau kesalahan semakin berkurang.

Tabel 2 Hasil estimasi karbon

\begin{tabular}{cccc}
\hline \multirow{2}{*}{ Titik } & \multirow{2}{*}{ Karbon Lapangan (ton) } & \multicolumn{2}{c}{ Karbon Estimasi (ton) } \\
\cline { 3 - 4 } & 1.3 & HH & HV \\
\hline $3-1$ & 0.57 & 1.10 & 1.37 \\
$3-2$ & 0.11 & 0.59 & 0.60 \\
$4-1$ & 0.04 & 0.505 & 0.595 \\
$4-2$ & 0.05 & 0.25 & 0.06 \\
$4-3$ & 0.44 & 1.011 & 0.911 \\
$5-1$ & 0.75 & 0.42 & 0.60 \\
$5-2$ & 0.75 & 0.77 & 0.81 \\
$7-3$ & & 0.84 & 0.78 \\
$8-2$ & 0.29 & 0.31 & 0.21 \\
\hline & & $\mathbf{0 . 3 8 3}$ & $\mathbf{0 . 3 5 7}$ \\
\hline
\end{tabular}

Analisis hubungan nilai backscatter dengan stok karbon secara umum dapat dilihat dari besar nilai R2 dari setiap persamaan regresi yang dihasilkan. Persamaan regresi quadratic menghasilkan nilai R2 pada polarisasi HV lebih besar dibandingkan dengan nilai R2 pada polarisasi HH. Berdasarkan nilai R2 pada persamaan regresi quadratic, hubungan antara stok karbon dengan polarisasi HH sebesar 0.588, sedangkan hubungan antara stok karbon dengan polarisasi HV sebesar 0.629. Besarnya koefisien determinasi menunjukkan bahwa pengaruh variable independent (polarisasi HV) terhadap simpanan karbon pada area kajian sebesar $62.9 \%$ sedangkan sisanya sebesar $37.1 \%$ dipengaruhi oleh variabel lain yang tidak dimasukkan dalam penelitian ini. Selain itu analisis statistik yang dilakukan untuk mengetahui hubungan nilai backscatter dengan stok karbon adalah dengan melihat nilai dari koefisien korelasi (R). Hasil analisis statistik menunjukkan bahwa nilai backscatter pada polarisasi HV dengan nilai stok karbon memiliki nilai koefisien korelasi sebesar 0.793. Nilai tersebut berarti terdapat korelasi yang sangat kuat, antara nilai backscatter mempengaruhi nilai stok karbon.

\section{SIMPULAN}

Total simpanan karbon atas permukaan pada tegakan di kawasan Tongke-tongke menggunakan persamaan regresi quadratic sekitar 5662.85 ton untuk citra dengan polarisasi HH dan 6431.46 ton untuk citra dengan polarisasi HV. 


\section{DAFTAR PUSTAKA}

Ahmed N, Glaser M. 2016. Coastal aquaculture, mangrove deforestation and blue carbon emissions: Is REDD+ a solution?. Mar. Policy. 66:58-66.

Alongi DM. 2008. Mangrove forests: Resilience, protection from tsunamis, and responses to global climate change. Estuarine, Coastal and Shelf Science. 76(1):1-13.

Alongi DM. 2014. Carbon sequestration in mangrove forests. Carbon Management. 3(3):313-322.

Aziz AA, Dargusch P, Phinn S, Ward A. 2015. Using REDD+ to balance timber production with conservation objectives in a mangrove forest in Malaysia. Ecol. Econ. 120:108-116.

Cramer W, Bondeau A, Woodward FI, Prentice IC, Betts RA, Brovkin V, Cox PM, Fisher V, Foley JA, Friend AD, Kucharik C, Lomas MR, Ramankutty N, Sitch S, Smith B, White A, Young-Molling C. 2001. Global response of terrestrial ecosystem structure and function to $\mathrm{CO}_{2}$ and climate change: Results from six dynamic global vegetation models. Global Change Biology. 7(4):357-373.

Das S. 2017. Ecological restoration and livelihood: Contribution of planted mangroves as nursery and habitat for artisanal and commercial fishery. World Dev. 94:492-502.

Departemen Kehutanan. 2011. Statistik Kehutanan Indonesia. Jakarta (ID): Kementerian Kehutanan.

Ewel KC, Twilley RR, Ong JE. 1998. Different kinds of mangrove forests provide different goods and services. Glob. Ecol. Biogeogr. Lett. 7(1):83.

FAO. 2007. The World's mangroves, 1980-2005: a thematic study in the framework of the global forest resources assessment 2005. Rome (IT): FAO Forestry Department.

Fawzi NI. 2016. Mangrove: Karakteristik, Pemetaan, dan Pengelolaannya. Yogyakarta (ID): Penerbit Sibuku.

Fei SX, Shan HC, Hua ZG. 2011. Remote Sensing of Mangrove Wetlands Identification. Procedia Environmental Sciences. 10:2287-2293.

Giri C, Mukhopadayay A, Hazra S, Mukherjee S, Roy D, Ghosh S. 2014. A study of abundance and distribution of mangrove spesies in Indian Sundaurban using remote sensing technique. Journal of Coastal Conservation. 18(4):359-367.

Goetz S, Baccini A, Laporte N, Johns T, Walker W, Kellndorfer J, Houghton R, Mindy. 2009. Review : mapping and monitoring carbon stocks with satellite observations: A comparison of methods. Carbon Balance and Management. 2009. 4:2.

Haryadi J, Hadiyanto. 2012. Korelasi nutrient terlarut dengan struktur komunitas plankton di Tambak Mangrove Blanakan Kab Subang. Jurnal Pengelolaan Sumberdaya Alam dan Lingkungan. 2(2):73-84.

Hilmi E. 2017. The carbon conservation of mangrove ecosystem applied REDD program. Reg. Stud. Mar. Sci. 16:152-161.

Howard J, Hoyt S, Isensee K, Telszewski M, Pidgeon E. 2014. Coastal Blue Carbon : Methods for assessing Carbon Stocks and Emissions Factors in Mangroves, Tidal Salt Marshes, and Seagrasses Meadows. Virginia (US): Conservation International, Intergovernmental Oceanographic Comission of UNESCO, International Union for Conservation of Nature.

Kauffman JB, Donato DC. 2012. Protocols for Measurement, Monitoring and Reporting of Structure, Biomass and Carbon Stocks in Mangrove Forests. Bogor (ID): Center for International Forestry Research (CIFOR).

Leung JYS. 2015. Habitat heterogeneity affects ecological functions of macrobenthic communities in a mangrove: Implication for the impact of restoration and afforestation. Glob. Ecol. Conserv. 4:423-433.

NASA. 2018. Climate Change: Climate Resource Center - Graphic: The relentless rise of carbon dioxide. 
Opa ET. 2010. Analisis Perubahan luas lahan mangrove di Kabupaten Pohuwato Propinsi Gorontalo dengan menggunakan citra landsat. Jurnal Perikanan dan Kelautan Tropis. 6(2):79-82.

Salam MA, Lindsay GR, Beveridge MCM. 2000. Ecotourism to protect the reserve mangrove forest the Sundarbans and its flora and fauna. Anatolia. 11(1):56-66.

Sifleet S, Pendleton L, Murray B. 2011. State of the science on coastal blue carbon a summary for policy makers. Nicholas Inst. Report. NI. 1-43.

Sutaryo D. 2009. Perhitungan Biomassa Sebuah Pengantar untuk Studi Karbon dan Perdagangan Karbon. Bogor (ID): Wetlands International Indonesia Programme.

Wang J, Rich PM, Price KP, Kettle WD. 2004. Relation between NDVI and tree productivity in the Central Great Plains. International Journal of Remote Sensing. 25(16):3127-3138.

Weiss F, Leip A. 2012. Greenhouse gas emissions from the EU livestock sector: A life cycle assessment carried out with CAPRI Model. Agriculture, Ecosystems \& Environment. 149:124-134.

Wicaksono P, Danoedoro P, Hartono, Nehren U. 2016. Mangrove biomass carbon stock mapping of the Karimunjawa Islands using multispectral remote sensing. International Journal of Remote Sensing. 37(1):26-52.

Wijayanto D, Nuriasih DM, Huda MN, Pamuntjak CRK. 2013. Strategies of Mangrove Tourism Development in Nusa Penida Marine Protected Area. J. Saintek Perikan. 8(2):25-32.

Yanuartanti IW, Kusmana C, Ismail A. 2016. Kelayakan rehabilitasi mangrove dengan teknik guludan dalam perspektif perdagangan karbon di kawasan hijau lindung muara angke prov dki jakarta. Jurnal Pengelolaan Sumberdaya Alam dan Lingkungan. 5(2):180-186.

Zagars M, Ikejima K, Kasai A, Arai N, Tongnunui P. 2013. Trophic characteristics of a mangrove fish community in Southwest Thailand: Important mangrove contribution and intraspecies feeding variability. Estuar. Coast. Shelf Sci. 119:145-152. 